DOI: https://doi.org/10.18309/anp.v51iesp.1516

\title{
O MOTIVO DO OLHAR: MISTÉRIOS DA ANIMALIDADE SEGUNDO C. L.
}

\section{THE MOTIF OF THE LOOKING: MYSTERIES OF THE ANIMALITY ACCORDING TO C. L.}

\author{
Priscilla de Souza Klein Gnutzmann \\ Universidade Estadual de Mato Grosso do Sul, Campo Grande, Mato Grosso do Sul, Brasil \\ priscillakleingnu@gmail.com \\ Rony Márcio Cardoso Ferreira \\ Universidade Federal do Mato Grosso do Sul, Campo Grande, Mato Grosso do Sul, Brasil \\ cardoso_rony@hotmail.com
}

Resumo: Por meio de uma leitura do conto "O búfalo", republicado por Clarice Lispector em Laços de família (1960), este artigo propõe um estudo sobre a relação do animal humano e não humano a partir das proposições de Jacques Derrida (2002) e Giorgio Agamben (2017). Postulamos existir uma correspondência entre a mulher do conto e alguns animais do zoológico, os quais figuram como pontos de reflexos frente aos medos e anseios da personagem humana. Essa correspondência torna-se aceitável na medida em que a narrativa problematiza o tema da alteridade animal, bem como ilustra ficcionalmente a imbricada relação de animalidade entre o homem e o inumano. Valeremo-nos, assim, das premissas teóricas dos Estudos Animais em interface com os estudos literários, tal como proposto por Maria Esther Maciel (2016) e outros críticos que já trataram da presença dos animais na literatura de Clarice, a exemplo de Silviano Santiago (2006) e Evando Nascimento (2012).

Palavras-chave: Animalidade; Humanidade; Alteridade animal; Crítica literária; Clarice Lispector

Abstract: Through the reading of the short story "O búfalo", republished by Clarice Lispector in Laços de Familia (1960), this article proposes a study on the relation between the human and the non-human animals from the propositions of Jacques Derrida (2002) and Giorgio Agamben (2017). We postulate that may exist a correspondence between the woman of the story and some animals of the zoo, which figurate as reflection points in front of the human character's fears and yearnings. This correspondence becomes acceptable as the narrative problematizes the theme of the animal alterity, as well as fictionally illustrates the intricated relation of animality between the human and the non-human. F or these reasons, we used the theorical premises of the Animal Studies in interface with the literary studies, as proposed by Maria Esther Maciel (2016) and some other critics who have already studied about the presence of the animals in Clarice's literature, such as Silviano Santiago (2006) and Evando Nascimento (2012).

Keywords: Animality; Humanity; Animal alterity; Literary criticism; Clarice Lispector 


\title{
1 Considerações iniciais: Clarice, a literatura e os animais
}

\begin{abstract}
Esta noite um gato chorou tanto que tive uma das mais profundas compaixões pelo que é vivo. Parecia dor, e, em nossos termos humanos e animais, era. Mas seria dor, ou era "ir", "ir para"? Pois o que é vivo vai para (LISPECTOR, 1999a, p. 33).
\end{abstract}

O conto "O búfalo" foi primeiramente publicado por Clarice Lispector na revista Senhor em 1960, logo depois do regresso da escritora ao Brasil. A revista dirigida por Paulo Francis teve o papel de divulgar as narrativas curtas de Clarice para um público maior, que a conhecia, sobretudo, devido à publicação dos primeiros romances: Perto do coração selvagem (1943), O lustre (1946) e A cidade sitiada (1949). A partir de 1959, Lispector voltou a exercer a função de jornalista em alguns periódicos da época: escreveu para a revista Senhor, manteve uma coluna no jornal carioca Correio da manhã, passando também a publicar no Diário da noite, no ano seguinte. Mais tarde, durante a década de 1960, intensificou seu trabalho como jornalista, fazendo entrevistas com escritores e personalidades, que foram reunidas em Diálogos possiveis da revista Manchete. Manteve também por sete anos (1967-1973) uma coluna de crônicas semanais no Jornal do Brasil e, nos últimos dois anos de vida, fez entrevistas para a revista Fatos \& Fotos. Junto a escrita de obras ficcionais e de textos para a imprensa, Lispector também traduziu cerca de quarenta títulos entre 1960 e 1977, ano de sua morte.

Nesse período de trabalho intenso, Clarice escreve e publica o conto "O búfalo", que mais tarde integraria o volume intitulado Laços de família (1960), coletânea em que reuniu contos já escritos no período em que esteve fora do Brasil, bem como narrativas inéditas. A escritora problematizou em vários desses contos a complexa relação entre seres, coisas e bichos, viventes e não viventes, apelando a uma convivência entre eles por meio de aproximações e distanciamentos, hospitalidade e estranhamento, similitude e diferença. Grosso modo, a crítica notou, neste caso, em vez de tolerância paternalista, segurança autoprotetora e egoísta, desprezo ignorante, além de uma espécie de mutação de valores entre tais seres, como se a escritora quisesse fazer de sua ficção o local da possibilidade infinita de compartilhamento e negociação das diferenças.

No conto "O búfalo", por exemplo, há uma troca de olhares entre o animal e a personagem humana, ato tão intenso que acaba por provocar nela um estado de vertigem. A narrativa resume-se na história de uma mulher que vai ao zoológico em busca de um possível "ponto de ódio", na intenção de lidar com uma recente decepção amorosa. No entanto, a personagem acaba por encontrar no olhar de um búfalo algo que a vira do avesso. É como se Clarice tentasse evidenciar o reconhecimento dos humanos em animais, associado à própria busca demasiadamente existencial do homem. Essa correspondência torna-se aceitável na medida em que o conto problematiza o tema da alteridade animal, ilustrando ficcionalmente a imbricada relação de animalidade entre o humano e o não humano.

Para tanto, o presente artigo se estrutura em três momentos, seguidos, por sua vez, das considerações finais. A segunda seção busca, por meio dos postulados de Aristóteles (2006), Jacques Derrida (2002) e Maria Esther Maciel (2016), apresentar uma reflexão sobre as possíveis interfaces entre os Animal Studies e os estudos literários, tendo como pano de fundo as problematizações propostas pela própria literatura acerca da animalidade e dos limites do humano. A terceira objetiva elucidar, a partir das propostas de Giorgio Agamben (2017), em que medida, ao longo dos tempos, a relação entre o humano e o inumano se efetivou sob a égide de instâncias reguladoras típicas do discurso ocidental. Por fim, a quarta visa a uma leitura mais 
pontual do conto de Clarice Lispector, sobretudo das passagens nas quais o olhar humano e o inumano se cruzam em intrigante estado de comunicabilidade.

\title{
2 Estudos da animalidade e estudos literários: interfaces
}

O pensamento do animal, se pensamento houver, cabe à poesia (DERRIDA, 2002, p. 22).

Com o passar do tempo e a propagação do discurso ocidental, houve um assujeitamento cada vez mais maior do animal não humano frente ao homem. Reiteradamente, o animal passou a ser utilizado como objeto de estudo em experimentações genéticas e inseminações artificiais. Ao mesmo tempo em que isso acontecia, a literatura, a filosofia e as ciências humanas de modo geral trouxeram para suas páginas uma reflexão a respeito de tais problemas, tanto em cenário nacional quanto internacional. No âmbito teórico, Aristóteles (2006) foi um dos primeiros pensadores a problematizar questões inerentes aos animais não humanos. No relato presente em História dos Animais, Aristóteles

\begin{abstract}
Pôs então sob sua orientação [...] milhares de homens que viviam da caça, da criação de aves, da pesca, ou que mantinham viveiros, rebanhos, colmeias, tanques, aviários, de modo a que nenhuma espécie escapasse ao conhecimento. Depois de interrogar estes indivíduos, Aristóteles escreveu cerca de cinquenta volumes célebres sobre os animais (SILVA, 2006, p.14).
\end{abstract}

As informações colhidas e catalogadas por Aristóteles tiveram grande credibilidade. Porém, com os discursos filosóficos e críticos do século XX, suas proposições tornaram-se obsoletas, apesar de serem constantemente revistas até os dias de hoje. Além da observação, Aristóteles realizou uma experimentação direta e pessoal, inclusive no que diz respeito às emoções registradas em algumas espécies animais. O pensador inaugurou, com isso, uma lógica ocidental que procurou observar e estudar o animal a partir de seu comportamento. Os estudos aristotélicos concederam margem para o surgimento de mitos e ditos populares, que foram radicalmente questionados pela filosofia de nosso tempo.

Proposições generalizadas a respeito dos animais também foram reproduzidas em distintas tradições poéticas, utilizadas como estratégias pedagógicas e culturais, corroborando algumas considerações cientificistas. Homero, por exemplo, refere-se com frequência aos animais de forma semelhante ao pensamento exposto por Aristóteles. Vale ressaltar que o autor de Arte poética se centrou na "pretensão de um aprofundamento do saber, orientado por uma multiplicidade de questões de princípio que permitem um espectro ampliado de interrogações" (SILVA, 2006, p. 28). Por isso, não se voltou às emoções e sensações experienciadas pelos animais, apenas procurou, em poucos casos, mapear sensações repetidas, pois sua investigação tratou exclusivamente da fisiologia animal, que serviu de base para posteriores estudos a respeito das mudanças significativas das espécies frente ao meio em que vivem, bem como em suas relações com o homem.

Jacques Derrida, em O animal que logo sou (A seguir) (2002), alega que o pensamento ocidental converteu o animal em um teorema, objeto visto mas que não vê. Derrida reivindica, ao longo de sua reflexão, a urgência de considerarmos a experiência do animal que, de certa forma, foi negligenciada por Descartes, Kant, Heidegger, Lacan e Levinas. Nas palavras de Derrida, os discursos desses filósofos 
[...] são fortes e profundos, mas neles tudo se passa como se eles nunca tivessem sido vistos, sobretudo não nus, por um animal que se dirigisse a eles. Tudo se passa ao menos como se a experiência perturbadora, supondo que ela lhes tenha ocorrido, não tivesse sido teoricamente registrada, precisamente lá onde eles faziam do animal um teorema, uma coisa vista mas que não vê (DERRIDA, 2002, p. 33, grifo do autor).

Em outras palavras, está nas entrelinhas do postulado derridiano a proposta de uma revisão das várias proposições que anularam a experiência do olhar do próprio animal. Foi nesse sentido que Maria Esther Maciel (2016) interpretou esse "teorema" logocêntrico como ferramenta que justificou a pretensa superioridade da razão e da linguagem humanas enquanto "propriedades diferenciais (e superiores) dos homens em relação aos outros viventes" (MACIEL, 2016, p. 38). Se, por um lado, essa superioridade se viu reforçada no âmbito do discurso teórico, por outro, a literatura enquanto potencializadora de saberes trouxe à cena a importância da "experiência do animal que vê" (DERRIDA, 2002, p. 33), mesmo quando se propõe a perscrutar o que há de mais íntimo no homem. Textos de Guimarães Rosa, Carlos Drummond e Clarice Lispector são exemplares, neste caso, para ficarmos apenas no âmbito da literatura brasileira.

Esse pensamento da teoria ocidental ganhou maior ênfase com Descartes, no século XVII, quando divulgou a ideia de que os animais são como máquinas. Assim, além de negar a racionalidade dos animais, Descartes também rejeitou suas emoções, afirmando que o comportamento corporal dos não humanos poderia ser visto como algo mecânico, não sendo necessário recorrer ao conceito de alma. Nesse sentido, permitiu-se a interpretação de que os animais não sentem dor, pois o que ocorre com eles são apenas movimentos da matéria. A partir de tal pensamento, a humanidade se colocou como dominadora da natureza sem ao menos se questionar a respeito do sofrimento ao qual o outro poderia estar submetido.

Para desconstruir essa visada, Derrida realizou uma crítica implacável às falsas oposições que separaram a espécie humana das demais espécies, questionando, passo a passo, os chamados "próprios do homem" (DERRIDA, 2002, p. 17) - linguagem, pensamento, riso, nudez, consciência da morte, uso de utensílios, capacidade de responder, mentir e apagar os próprios rastros, entre outros -, que serviram não apenas para o estabelecimento de uma radical cisão entre homem e animal, humanidade e animalidade, como também para a legitimação das práticas humanas de violência contra os demais viventes. Para o filósofo franco-argelino, as tradições ocidentais e os estudos sobre a animalidade foram por muito tempo logocêntricos, constatação que guiou o pensamento derridiano para uma desconstrução do humanismo ocidental.

Por isso, Derrida procurou refletir sobre a condição do animal a partir do descentramento do discurso que sustentou a agressão a que foram acometidos os animais não humanos na história do homem. O pensador apontou, em sua releitura da tradição ocidental, aquilo que fora valorizado e em nome de quê, ao mesmo tempo que trouxe à tona os aspectos dissimulados por tal discurso. Questionou também os pressupostos filosóficos e denunciou seus fundamentos fono e etnocêntricos. Conforme Maciel (2016), Derrida revisou o emprego do singular genérico "animal" para englobar uma multiplicidade de espécies diferentes:

Daí a proposta do filósofo de se substituir a palavra "animal" pelo neologismo (uma palavra-valise) "animot", como forma de fazer ouvir, no singular da palavra animal, o plural "animais" (animaux) e mostrar como a linguagem afeta o nosso acesso à complexidade do mundo não humano. Isso, mesmo sabendo que o termo não passa de um artifício, um nome forjado pela razão, ou uma quimera, já que todo conceito de animal ou de animais é sempre uma construção humana (MACIEL, 2016, p. 41). 
Essas questões foram desdobradas e verticalizadas no seminário La Bête et le souverain [A besta e o soberano], ministrado por Derrida entre 2001 e 2003, em Paris. Na primeira parte, Derrida destaca o tema da associação e dissociação de classes, frequente ao longo da história da filosofia, comum às figuras do soberano e da besta, indagando os meios ou mecanismos que, de alguma forma, propuseram a separação hierárquica entre eles. O pensador designou essa artimanha ocidental como o fundamento político-teológico da soberania. $\mathrm{Na}$ segunda parte, abordou as questões da vida animal e sua relação com o homem. As teses do seminário explicaram o que, para Heidegger, era a eminência inegável do homem em relação ao animal, diante da falta de palavra, fala, afeto e verdade, que, em seu conjunto, corroborou a impossibilidade animal de definir o mundo. A partir de uma espécie de enfrentamento dos postulados de heideggerianos, Derrida formula as seguintes perguntas: "Quem sou eu então? Quem é este que eu sou? A quem perguntar, senão ao outro?” (DERRIDA, 2002, p. 18).

Nessa perspectiva, o outro é aquele ante do qual alguém está desarmado e indefeso, aquele que pode sobreviver ao outro, sobreviver a sua morte e fazer com seus restos, soberanamente, qualquer coisa. Em contrapartida, o outro é também o único que pode devorálo vivo, dispor de seus restos mortais, sem esperar por sua morte. Derrida tratou, em momentos centrais de seu seminário, de uma das privações do animal, apontada insistentemente por Heidegger: a falta de $\log o s$, a incapacidade de falar, de ter a linguagem do homem e de se relacionar com o mundo seguindo a lógica humana (cf. MACIEL, 2016, p. 38).

Derrida também discutiu e repensou os aspectos que levaram o humano ao aproveitamento do não humano para supressão das suas necessidades sem a devida análise do sofrimento causado ao inumano. No âmbito geral, suas reflexões partem de algumas questões: quem é o animal? Quem é o outro? Quem sou eu diante de um gato me olhando nu diante de um espelho? Tais questões se justificam, sobretudo, quando o pensador afirma: "frequentemente me pergunto, para ver, quem sou eu - e quem sou eu no momento em que, surpreendido nu, em silêncio, pelo olhar de um animal, por exemplo os olhos de um gato, tenho dificuldade, sim, dificuldade de vencer um incômodo" (DERRIDA, 2002, p. 15, grifo do autor).

Esse incômodo que perpassa as reflexões de Derrida torna-se importante, pois ele é fruto de um desconcerto da voz que se enuncia no próprio discurso filosófico, a qual se vê impossibilitada de descrever a forma como o outro (o animal) o olha: "Há muito tempo, podese dizer que o animal nos olha? Que animal? O outro?” (DERRIDA, 2002, p. 15). Por isso, o pensador franco-argelino questiona a relação entre o homem e os demais viventes, indagando as teorias ocidentais sobre animalidade e humanidade que são dominantes na tradição filosófica. Para tanto, o livro de Derrida torna-se, grosso modo, uma espécie de mal-estar humano decorrente da dificuldade sentida pelo homem a partir do momento em que o olhar de um animal (um gato) é lançado sobre si. Em outros termos, o próprio discurso de $O$ animal que logo sou parece ser o resultado de "[...] um mal-estar de um tal animal diante de outro animal" (DERRIDA, 2002, p. 16).

Toda essa questão está perpassada, nas reflexões de Derrida, pelo caráter da nudez que caracteriza o humano, cuja história é marcada pela vergonha de estar nu frente a um outro animal não humano, uma vez que apenas o homem inventou uma vestimenta para si e, por isso, tornou-se capaz de nudez. Já o animal, portanto, nunca está nu, porque ele é nu. A partir dessa contraposição, Derrida conclui que para o inumano não existe nudez, visto que ele não se vê, nem se sente nu, estando alheio tanto ao pudor quanto ao impudor da humanidade. Assim, a experiência da nudez passa a ser considerada um "próprio do homem, quer dizer, estranha aos animais, nus como são" (DERRIDA, 2002, p. 16). A nudez seria, então, um dos muitos aspectos 
singularizadores da forma como o homem se relaciona com o mundo, forma essa que sempre privou os animais (o outro, o estranho) do direito à resposta, devido ao não compartilhamento de uma mesma linguagem, fala e palavra.

Derrida declara que se apenas os homens são seres racionais, isso é o que aparentemente os difere dos demais viventes. Essa concepção advinda da filosofia ocidental, além de considerar o humano não só diferente do não humano, dá àquele o direito de usar os outros seres vivos para satisfação de seus propósitos, pois a razão seria o elemento estabelecedor de uma relação hierárquica, promovendo a elevação do humano e o rebaixamento do não humano, do diferente, do outro. O grande problema, para Derrida, está no fato de que grande parte dos pensadores viu, observou, analisou e refletiu sobre o animal, mas não se viu observada pelo inumano, ou seja, muitos textos do pensamento ocidental foram assinados por pessoas que

não puderam ou não quiseram tirar nenhuma consequência sistemática do fato que um animal pudesse, encarando-as, olhá-las, vestidas ou nuas, e, em uma palavra, sem palavras dirigir-se a elas; absolutamente não tomaram em consideração o fato que o que chamam "animal" pudesse olhá-las e dirigir-se a elas lá de baixo, com base em uma origem completamente outra (DERRIDA, 2002, p. 32, grifos do autor).

Foi por meio dessa relação de supremacia humana quanto à forma de ver o mundo, que os animais foram julgados e vistos ao longo da história. Daí igualmente advém o primado da racionalidade do homem, que buscou entre os seus semelhantes um fim de identificação e, por conseguinte, a instituição de uma linguagem da palavra, que concede margem à humanidade para falar em "uma só voz do animal" (DERRIDA, 2002, p. 62), designando a ele, o papel de ser que ficou sem resposta. Logo, ao termo "animal" subjaz, conforme Derrida, um mal, já que a palavra em si resumiria todo um intento humano em busca de um processo de identificação, ou seja, um processo de reconhecimento "com vistas a ser o que eles se dizem ser, homens, capazes de responder e respondendo em nome de homens" (DERRIDA, 2002, p. 62).

Da mesma forma que o problema da animalidade suscitou discussões no plano filosófico, ele se prefigurou importante na escrita de várias literaturas. Segundo Maciel (2006), podemos falar de um novo espaço poético-ficcional que passou a acolher a temática dos animais, tornando-se também a literatura "um ponto de confluência de todas as zoologias possíveis e impossíveis" (MACIEL, 2006, p. 20). Tal confluência se concretiza por meio de registros literários de diferentes tempos e espaços, incluindo culturas do Oriente e do Ocidente, bem como criando vários seres fantásticos não circunscritos à esfera animal, como elfos, gnomos, fadas e anjos. Assim, frente aos bestiários fantásticos e às inúmeras coleções de textos sobre animais, a "zooliteratura", ao longo dos dois últimos séculos, apresentou-se sob inúmeras configurações.

Muitos escritores destacam-se como "animalistas", inserindo em suas obras diferentes categorias do mundo animal, como a das feras enjauladas nos zoológicos, dos bichos domésticos e rurais, das cobaias e das espécies em extinção. Entre esses escritores, Maciel (2016) destaca Franz Kafka, J. M. Coetzee, Paul Auster, Lydia Davis, Luiza Neto Jorge, entre outros, sem contar nos vários escritores brasileiros que produziram uma espécie de "zoopoética" cujo papel foi o de não somente escrever sobre os animais, mas abordá-los como sujeitos dotados de sensibilidade, inteligência e conhecimentos.

Para conceituar o que entende por "zoopoética" e "zooliteratura", Maciel recorre ao estudo de Derrida aqui já tratado. Segundo a estudiosa, $O$ animal que logo sou tornou-se seminal para a relação entre os estudos literários e os estudos da animalidade, pois o filósofo 
utiliza os termos "zoopoética" e "zooliteratura" para problematizar a presença de animais nas obras de Kafka, Baudelaire, Rilke, Carrol e Hoffman. Podemos dizer, então, que ensaio de Derrida abriu caminho para que crítica do século XX sistematizasse tais termos enquanto noções capazes de reunir sob a mesma rubrica obras e escritores voltados à ficcionalização das diferentes abordagens sobre o animal não humano. Nas palavras de Maciel,

O termo zoopoética poderia ser empregado para designar tanto o estudo teórico de obras literárias e estéticas sobre animais quanto a produção poética específica de um autor, voltada para esse universo "zoológico" [...]. As diferenças entre zooliteratura e zoopoética seriam, portanto, as mesmas entre literatura e poética, mas acrescidas do valor semântico do prefixo "zo(o)” (MACIEL, 2016, p. 15).

Essa recente atenção dada aos animais no pensamento contemporâneo tanto modificou a forma como eles foram vistos e abordados na tradição ocidental, quanto levou o homem a repensar a sua "animalidade perdida ou recalcada" (MACIEL, 2016, p. 16). Jorge Luis Borges, por exemplo, no prólogo ao volume Manual de zoología fantástica (1957), ajudou de certa forma a sistematizar as relações existentes entre a literatura enquanto campo de investigação e os estudos da animalidade. $\mathrm{O}$ escritor argentino concebeu a existência, na literatura, de um jardim zoológico da realidade composto por animais existentes e de um jardim zoológico das mitologias habitado por seres fantásticos (BORGES; GUERRERO, 1957, p. 7-9). Partindo, então, das proposições do filósofo franco-argelino e das inferências do escritor argentino, podemos afirmar, de antemão, que o conto de Clarice se prefigura enquanto uma espécie de zooliteratura da realidade, como veremos mais adiante.

Maciel alega que as obras de Borges sobre os animais contribuíram para uma revisão da zooliteratura anterior e, simultaneamente, serviram de textos precursores a uma literatura da animalidade na hispano-américa do século XX. Em virtude disso, a estudiosa brasileira pontua que não há como negar a existência de uma configuração zooliterária e zoopoética a partir dos séculos XIX e XX nas diversas literaturas, razão que levou Maciel a elencar, em uma vasta lista, escritores que podem ser, considerando seus traços particulares "de fazer do animal um animal escrito" (MACIEL, 2016, p. 25), nomeados como "animalistas", a exemplo de Clarice Lispector.

\section{O aberto, o homem e o animal no pensamento contemporâneo}

\footnotetext{
Em nossa cultura, o homem [...] tem sido sempre o resultado de uma divisão, e ao mesmo tempo de uma articulação do animal com o humano, na qual um dos dois termos da operação era também o que estava em questão. Tornar inoperante a máquina que governa a nossa concepção do homem não significará, portanto, buscar novas - mais eficazes ou mais autênticas - articulações, quanto exibir o vazio central, o hiato que separa - no homem - o homem e o animal [...] (AGAMBEN, 2017, p. 143).
}

Avançando, assim como Jacques Derrida (2002), os postulados da tradição fillosófica a respeito da relação homem/animal, Giorgio Agamben (2017) problematiza o que particulariza o "humano", procurando desfazer a falácia de que o homem é um animal superior aos outros animais. Com base em textos dos antigos gregos, cristãos e judeus do século XX, bem como das propostas de Heidegger, Benjamin e Kojève, o filósofo italiano analisa de que modo a distinção entre o homem e o animal acabou por ser forjada no Ocidente. Para tanto, investiga 
as implicações dessa distinção frente aos discursos epistemológicos de várias áreas do conhecimento (a filosofia, o direito, a antropologia, a medicina, a política, entre outras).

Agamben, a partir dos pressupostos heideggerianos - a "pobreza de mundo" do animal e o homem como "formador de mundo" -, interroga a origem e o sentido da abertura produzida pelo homem no ser vivo. Segundo Agamben, Heidegger refutava a definição metafísica tradicional do homem como animal racional, o ser vivo que possui a linguagem (ou a razão), quase como se o ser do homem fosse determinável por meio da adição de qualquer coisa ao "simplesmente vivo" (HEIDEGGER, apud AGAMBEN, 2017, p. 80). A exposição de Heidegger é constituída por uma tese tripla: "a pedra é sem mundo [...], o animal é pobre de mundo [...], o homem é formador de mundo [...]" (HEIDEGGER, apud AGAMBEN, 2017, p. 82). Nas palavras de Heidegger, "somente porque o animal é em essência atordoado ele pode comportar-se [...]. O atordoamento é a condição de possibilidade graças a qual o animal, segundo a sua essência, se comporta em um ambiente, mas nunca em um mundo" (HEIDEGGER, apud AGAMBEN, 2017, p. 84).

Para revisar a tese de Heidegger, Agamben formula uma noção: o "aberto", que, segundo ele, é característico da faculdade humana, uma espécie de abertura ao mundo que permite o desvelamento do ente. Por isso, o aberto, assim como proposto pelo filósofo, revelase melhor quando comparamos a percepção humana do mundo e a percepção do ambiente pelo animal. Na visão de Agamben, as tentativas científicas de definição do homem tornaram-se vazias e elásticas, pois se alteraram conforme o contexto histórico e político de cada época, acarretando em uma consequente antropomorfização do animal e animalização do homem.

Sob essa égide, o homem passa a ser visto como o ser aberto, por isso não suscetível à definição redutora. Agamben evidencia, assim, que o aberto não pode ser compreendido a partir de uma ciência dos entes, tal como propôs o biologismo do século XIX e a própria psicanálise. Segundo ele, o pensador alemão quis, com sua tese, negar radicalmente qualquer visão mecânica, dualista ou entificada do homem. Por isso, a noção formulada pelo pensador italiano não corresponde a uma definição filosófica, visto que a ideia foi por ele reassumida na história da filosofia com base em uma abordagem política do tema, passando a ser a ciência, neste aspecto, uma ação legisladora das decisões públicas sobre o que é o homem.

Para tanto, Agamben vale-se da biofilosofia e da antropologia filosófica, deixando nítido, logo no início de seu livro, que a filosofia da natureza é fundamental para a filosofia do homem, pois, por meio da figura de um animal, o homem é capaz de se projetar, como em uma espécie de autoimagem, assim como acreditamos ocorrer na urdidura ficcional do conto clariciano. Essas proposições são notadas desde as epígrafes com as quais Agamben abre seu livro $O$ aberto: o homem e o aninal:

Se os animais não existissem, a natureza do homem seria mais incompreensível (BUFFON, apud AGAMBEN, 2017, p. 7).

Tinham [os homens] necessidade deles [os animais], no entanto, a fim de tomar conhecimento experimental de sua natureza (AQUINO, apud AGAMBEN, 2017, p. 7).

Segundo Ranieri Ribas (2013), na primeira epígrafe, a proposição do que vem a ser o animal, é, também, uma proposição do que é o homem. A partir dessa premissa, Agamben opta por conceber o homem enquanto conceito, uma categoria aberta, cheia de inconstâncias e mudanças, sendo sua própria descrição um ato político. Ainda conforme Ribas, a segunda epígrafe propõe que a figura do animal levaria o homem a se conhecer, mesmo que esse 
conhecimento se efetive a partir da sua própria autoimagem, situação essa emblemática como veremos adiante nos fragmentos do conto de Lispector.

No primeiro capítulo do livro, Agamben trata de uma alegoria extraída da Bíblia hebraica do século XIII disponível na Biblioteca Ambrosiana de Milão. Segundo a perspectiva do profeta Ezequiel, o desenho - reproduzido, por sua vez, no verso da folha de guarda da edição da tradução brasileira do livro de Agamben - representaria o banquete dos justos no Último Dia, os quais representariam toda humanidade, ainda que composta por figuras de homens com cabeça de animais, bico de águia, cara de boi e leão, além de traços de asno e aparência de pantera. Nesse banquete, estão também reproduzidos dois instrumentistas que tocam e animam o lugar, um deles com a cabeça de macaco. $\mathrm{O}$ alimento posto à mesa, como manda a tradição rabínica, é composto por animais: o pássaro Ziz, o boi Behemot e o grande peixe Leviatã.

De acordo com a leitura de Agamben, a imagem pode representar a história da humanidade, apesar de o filósofo se declarar intrigado com a representação dos homens com traços animalescos. Embora admita a incoerência de uma única leitura da imagem, Agamben passa a descrever possíveis explicações. Em uma delas, a justificativa da representação do homem com traços de animais se dá porque a humanidade, após a morte, seria transformada em estrelas e se identificaria com os governantes do céu, simbolizados por animais. A outra explicação, de tradição rabínica, propõe ver os justos não como mortos, mas vivos à espera do Messias. Já conforme os textos dos maniqueus, esses justos corresponderiam ao reino animal (bípedes, quadrúpedes, aves, peixes e répteis), e todos, às cinco naturezas do corpo humano (ossos, nervos, veia, carne e pele).

Agamben acredita que essas figuras desenhadas há mais de nove séculos problematizam as possíveis relações entre humano/animal e seus subsequentes questionamentos a respeito da máquina antropológica do animal humano e não humano. Essa questão foi analisada por muitos estudiosos ao longo dos séculos, visto que o pós-histórico humanístico continua um mistério a ser estudado. Nas palavras de Agamben,

[...] não é impossível que, ao atribuir uma cabeça animal ao resto de Israel, o artista do manuscrito da Ambrosiana tenha tentado demonstrar que, no último dia, as relações entre os animais e os homens serão compostas de uma nova forma e o próprio homem se reconciliará com a sua natureza animal (AGAMBEN, 2017, p. 12).

Se proposições como essa já se fizeram presentes ao longo dos tempos, podemos dizer que não somente as artes plásticas e/ou os discursos filosóficos e biológicos se ocuparam delas, pois a própria literatura também tratou, em diferentes contextos, de tais questões. Torna-se importante salientar que Agamben inicia sua reflexão a partir da imagem devido à histórica discussão entre Georges Bataille e Alexandre Kojève. Sob a perspectiva de Agamben, Kojève teria notado que o devir pós-histórico do homem já teria ocorrido, pois a humanidade sempre trouxe consigo uma visão animal da humanidade, dividindo o mundo entre os animais não humanos e os humanos propriamente ditos. Agamben pontua que Kojève vê o homem como um "campo de tensões dialéticas" (AGAMBEN, 2017, p. 24), que está cindido entre "a animalidade antropófora e a humanidade que nela se encarna" (AGAMBEN, 2017, p. 24).

$\mathrm{Na}$ esfera desse campo de tensões, Agamben concebe a ironia como a máquina antropológica do humanismo. Para o filósofo, há um suspenso, um aberto entre o animal e o humano, em cuja relação se interpõe sempre uma contextualização política que o caracterize. Essa ironia se manifesta, nesse sentido, por meio das tentativas de autodefinição e 
autoclassificação do próprio homem, as quais procuram apresentar um reconhecimento do eu em relação ao outro como semelhante, permanecendo, então, indefinido, em aberto.

$\mathrm{Na}$ tentativa de reconstruir a história da evolução do homem, a paleoantropologia e a anatomia comparada fizeram referência a um elo perdido entre o homem e o macaco. Segundo Ribas (2013), foi com Ernst Haeckel que a busca de um "animal intermediário" na escala evolutiva dos hominídeos se tornou uma obsessão científica. Haeckel refere-se à passagem dos macacos antropomorfos ao homem tomando por intermediário uma espécie de homem-macaco privado de linguagem, denominado cientificamente como Pithecanthropus alalus. Mas, para Agamben, essa comparação entre o homem e o animal não é plausivelmente explicitada por esse viés, pois

Exatamente simétrico é o funcionamento da máquina dos antigos. Se, na máquina dos modernos, o fora é produzido por meio da exclusão de um dentro e o inumano animalizando o humano, aqui o dentro é obtido por meio da inclusão de um fora, o não-homem por meio da humanização de um animal: o macaco-homem, mas também e acima de tudo o escravo, o bárbaro e o estrangeiro enquanto figuras de um animal em forma humana (AGAMBEN, 2017, p. 62).

Conforme Agamben, Jakob von Uexküll, considerado um dos maiores zoólogos do século $\mathrm{XX}$, concebeu a existência de uma infinita variedade de mundos perceptíveis, todos igualmente perfeitos e ligados entre si. Discordando do prisma clássico, que tomava o mundo como único, geral e abarcador de todas as espécies viventes, as quais seriam hierarquicamente ordenadas, Uexküll propõe a não existência de um mundo unitário, da mesma forma que não existe um tempo e um espaço idêntico a todos os viventes.

A teoria de Uexküll, na visão de Agamben, não é resultado de uma filosofia ou de um pensamento autêntico, ela resulta, na verdade, da observação empírica da natureza. Porém, o filósofo italiano reconhece que Heidegger se apropriou dos conceitos de Uexküll relendo sua noção de Umwelt. Heidegger afirma, segundo Agamben, que o animal é pobre de mundo porque a sua relação com os portadores de significados dá-se somente pelo instinto, pois o animal está aberto somente ao que é alcançável a ele, visto que se comporta apenas dentro das possibilidades já postas. Nesse sentido, o entendimento do animal não alcança o mundo dos entes, enquanto possibilidade infinita para a construção do humano.

Assim, para Agamben, o pensamento heideggeriano concebe a existência de um parentesco entre a criatura e o criador. Esse parentesco possibilitaria um caminho de plenitude ao significado mais profundo, que o filósofo alemão denomina de "ser-aí", e, ao mesmo tempo, suscita uma aproximação entre o instinto animal e o tédio humano. Dito de outro modo, o atordoamento animal é semelhante ao tédio do homem, visto que

O homem que se entedia vem a se encontrar numa "proximidade extrema" - ainda que aparentemente - do atordoamento animal. Ambos estão, em seu gesto mais próprio, abertos a um fechamento, integralmente entregues a algo que se recusa obstinadamente (AGAMBEN, 2017, p. 105, grifo do autor).

A noção heideggeriana do "ser-aí" corresponde ao "ser mantido em suspenso no nada, quase a mesma palavra que define a segunda dimensão essencial do tédio" (HEIDEGGER, apud AGAMBEN, 2017, p.110). Em virtude disso, a categoria do humano se ocupa em despertar no vivente o seu instinto, a um abrir-se angustiante e decidido, a um não-aberto. Assim, Heidegger, na leitura de Agamben, acaba por negar a máquina do pensamento moderno e abrir um novo caminho reflexivo na história da filosofia em que o homem será considerado 
enquanto Ser em si. Torna-se operante ressaltar que Heidegger foi o último filósofo a crer que a pólis, onde reinava o conflito entre animalitas e humanitas, fosse ainda possível aos homens em busca de um destino histórico. Isto é, "ele foi [..] o último a crer [...] que a máquina antropológica, decidindo e recompondo, a cada vez, o conflito entre o homem e o animal, entre o aberto e o não-aberto, pudesse ainda produzir para um povo história e destino (AGAMBEN, 2017, p. 119).

É contra essa oposição que Agamben discorre em seu estudo. Para ele, a linguagem não é um elemento natural que, inscrito psicofisicamente, caracteriza o homem. Pelo contrário, a linguagem, em sua concepção, é um "produto histórico" (AGAMBEN, 2017, p. 60), sem o qual a diferença entre o humano e o inumano torna-se inoperante. Apesar dessa diferenciação inscrita historicamente, a relação entre o homem e o animal nunca deixou de existir, sendo prefigurada por vínculos que marcam os viventes: o afeto, a morte e o olhar, por exemplo. Entretanto, cabe ressaltar que essas marcas não se aproximam necessariamente por similitudes, já que, como afirmou Derrida (2002, p. 32), o ser designado como animal pode também dirigirse ao homem por meio do olhar, como veremos no conto "O búfalo", de Clarice Lispector.

\section{A animalidade segundo $C$. L.}

Não sei por quê, mas acho que os animais entram com mais frequência
na graça de existir do que os humanos. Só que eles não sabem, e os
humanos percebem. Os humanos têm obstáculos que não dificultam a
vida dos animais, como raciocínio, lógica, compreensão. Enquanto que
os animais têm a esplendidez daquilo que é direto e se dirige direto
(LISPECTOR, 1999a, p. 92).

Como podemos notar no fragmento epigráfico acima transcrito a partir de "Estado de graça - trecho", crônica publicada, em 06 de abril de 1968, no Jornal do Brasil e hoje reproduzida em $A$ descoberta do mundo (1999a), Clarice Lispector problematizou em sua prosa a intrínseca relação entre o homem e o animal, seja por aproximações ou afastamentos. A literatura da escritora, além de inscrever o animal como sujeito, converteu o inumano em ser literário na medida em que o homem, geralmente, se vê refletido no animal. Por consequência, vários textos da autora podem ser tomados como espaços de ficção em que o homem exercita a sua animalidade interior (MACIEL, 2016, p. 85).

Lispector escreveu, grosso modo, sobre o animal real, aquele relacionável ao homem por meio de um laço de afinidade. Esse animal caracteriza-se como persona que se identifica com o humano, em uma espécie de espelhamento, como se a escritora quisesse ilustrar poeticamente índices da animalidade humana. A partir disso, Maciel indaga: "Até que ponto, ao se valer da linguagem verbal para trazer à tona uma subjetividade estranha, que não se constitui ela mesma pela palavra, o escritor cumpre efetivamente seu intento de desvendar a outridade animal?" (MACIEL, 2016, p. 85). Esse intento da escritora (o ato de escrever o animal) acaba por desbaratar a diferença que se instituiu ao longo dos tempos entre o humano e o inumano, conforme bem ressaltamos a partir dos postulados de Derrida e Agamben.

Podemos dizer, assim, que Clarice conseguiu, por meio da escrita, chegar a este ponto de comunicação tão próximo em cujo mecanismo encontramos uma mistura entre o eu (personagem humana) e o outro (animal), deixando nítido o atravessamento da alteridade animal nas fronteiras do humano. Tal premissa torna-se aceitável, quando observamos que, em "O búfalo", é narrada a história de uma mulher que vai a um zoológico "para adoecer" (LISPECTOR, 2009, p.126). Ela busca, segundo o narrador, um "ponto de ódio" (LISPECTOR, 
2009 , p. 126) a partir do contato direto com o olhar das feras, as quais, de alguma forma, poderiam ajudar a personagem a enfrentar os momentos em que experiencia o ódio advindo de uma desilusão: “"Eu te odeio', disse ela para um homem cujo crime único era o de não amá-la. 'Eu te odeio', disse muito apressada" (LISPECTOR, 2009, p. 127).

Entretanto, a mulher "acaba por encontrar no olhar de um búfalo a violência do amor. Pela animalidade do búfalo ela se humaniza" (MACIEL, 2016, p. 86) e, simbioticamente, entra em contato com pensamento animal, pois ele, de certa forma, traduz em seu olhar todo o ódio sentido pela personagem humana. É como se a mulher desiludida se colocasse no lugar do búfalo e estabelecesse uma plena conexão. O primeiro contato da personagem com o animal, no âmbito narrativo, é atravessado por uma suspeição, pois ela se mostrava inclinada a não acreditar que o animal a olhava, como notamos na passagem a seguir:

E no silêncio do cercado, os passos vagarosos, a poeira seca sob os cascos secos. De longe, no seu calmo passeio, o búfalo negro olhou-a um instante. No instante seguinte, a mulher de novo viu apenas o duro músculo do corpo. Talvez não a tivesse olhado. Não podia saber, porque das trevas da cabeça ela só distinguia os contornos. Mas de novo ele pareceu tê-la visto ou sentido (LISPECTOR, 2009, p. 133, grifos nossos).

No decorrer do conto, a mulher olha o animal e o animal a olha. Isso desconcerta o seu mundo, deixando-a confusa frente aquilo que ela realmente procura: a aprendizagem do ódio através do animal, ódio tão verdadeiro e absoluto que ela imagina encontrar somente no outro. Todavia, cabe ressaltar que, antes mesmo do encontro com o búfalo, a personagem já tinha se deparado com o olhar penetrante e desconcertante do macaco e do quati, ficando em vários momentos pensativa, paralisada e perplexa diante das sensações que até então não imaginara sentir:

Um macaco também a olhou segurando as grades, os braços descarnados abertos em crucifixo, o peito pelado exposto sem orgulho. Mas não era no peito que ela mataria, era entre os olhos do macaco que ela mataria, era entre aqueles olhos que a olhavam sem pestanejar (LISPECTOR, 2009, p. 127).

De dentro da jaula o quati olhou-a. Ela o olhou. Nenhuma palavra trocada. Nunca poderia odiar o quati que no silêncio de um corpo indagante a olhava. Perturbada, desviou os olhos da ingenuidade do quati. O quati curioso lhe fazendo uma pergunta como uma criança pergunta. E ela desviando os olhos, escondendo dele a sua missão mortal (LISPECTOR, 2009, p. 130).

Essas duas passagens tornam-se emblemáticas na medida em que funcionam como espécie de prenúncio ao momento experiencial a que a personagem se direciona. No primeiro excerto, apesar de o narrador mencionar a posição dos braços e descrever rapidamente o peito do macaco, fica evidente a obsessão da mulher pelo olhar alheio. Mais intrigante ainda é a busca humana por esse olhar, como se ele fosse o ponto nevrálgico em que a personagem humana conseguiria despejar todo o seu ódio (a ação de matar). Já no segundo fragmento, embora tenhamos a troca recíproca de olhares entre o humano e o inumano, a personagem se sente acuada diante da posição indagadora e curiosa do quati, fato que impulsiona a continuidade de sua via crucis pelo zoológico.

Tais estranhamentos sentidos pela mulher são frequentes em toda a narrativa. Todavia, é a troca de olhar entre o búfalo e a personagem que a desconcerta completamente, pois o olhar do animal penetra em seu íntimo como se conseguisse sentir tudo o que a mulher sentia naquele momento. Portanto, a troca de olhar com o animal funciona enquanto descoberta íntima do 
próprio mundo da personagem, que se vê refletida e exposta ao mesmo tempo. Situação essa que a conforta, mas não deixa também de colocá-la como sujeito paradoxalmente intrigado frente a uma alteridade:

Ele se aproximava, a poeira erguia-se. A mulher esperou de braços pendidos ao longo
do casaco. Devagar ele se aproximava. Ela não recuou um só passo. Até que ele
chegou às grades e ali parou. Lá estavam o búfalo e a mulher, frente a frente. Ela não
olhou a cara, nem a boca, nem os cornos. Olhou seus olhos. E os olhos do búfalo, os
olhos olharam seus olhos. E uma palidez tão funda foi trocada que a mulher se
entorpeceu dormente. De pé, em sono profundo. Olhos pequenos e vermelhos a
olhavam. Os olhos do búfalo. A mulher tonteou surpreendida, lentamente meneava a
cabeça. O búfalo calmo. Lentamente a mulher meneava a cabeça, espantada com o
ódio com que o búfalo, tranquilo de ódio, a olhava (LISPECTOR, 2009, p. 135, grifo
nosso).

Após a contínua procura, a mulher se vê diante do búfalo e percebe que encontrara nos pequenos e penetrantes olhos vermelhos do animal o que tanto necessitava sentir na carne: o ódio. Essa percepção torna-se importante, pois ela passa a reconhecer a necessidade do outro, tanto é que espera a aproximação do animal, deixando, sem se mover, ser olhada por ele. $\mathrm{O}$ ódio do qual tanto precisava estava no olhar daquele animal negro, que se deixava olhar e a olhava com calma, como se entendesse tudo o que estava acontecendo no íntimo da personagem humana. Por isso, a mulher acaba se surpreendendo com a força do olhar animal, olhar demasiadamente natural e sincero, que justifica a sua ida ao zoológico. Por conseguinte, homem e animal são acometidos por uma reciprocidade que faz da mulher um sujeito mais humano, tendo por base a compreensão de sua própria animalidade.

O ato de olhar o animal e ser olhado por ele é uma constante na literatura de Lispector, basta apenas nos lembramos da conhecida passagem em que a protagonista de A paixão segundo G.H., diante do olhar da barata quase morta, afirma: "Toma o que eu vi: pois o que eu via com um constrangimento tão penoso e tão espantado e tão inocente, o que eu via era a vida me olhando" (LISPECTOR, 1996, p. 38). Em Clarice, o ato de olhar é ao mesmo tempo acompanhado por medo e liberdade, náusea e regozijo, ódio e encantamento, como no conto de Laços de família.

Não forçosamente, podemos dizer que Clarice prioriza, em várias de suas narrativas, a troca de olhares no ato de apreensão da alteridade animal. Sua literatura não apenas defende uma aproximação corporal e sensível entre os humanos e os demais viventes, mas também confere ao animal não humano o estatuto de sujeito e reconhece-o como um ser que, em sua singularidade, olha, sente, sofre e externaliza saberes próprios sobre o mundo. Lispector forja esse efeito em "O búfalo", visto que representa o animal como sujeito e principalmente consegue conferir a ele a visão de mundo e do homem (no caso do conto, a mulher do zoológico), distante de artifícios metafóricos.

Evando Nascimento (2012) explica que, na literatura de Clarice, o valor do não humano habita o coração do humano. Para o crítico, aquilo que se designa como negativo, o não humano, acaba sendo nos textos claricianos a fonte do próprio homem e da sua humanidade. $\mathrm{O}$ que os animais teriam em comum com o homem, segundo a ficção de Lispector, seria o partilhar de uma mesma origem múltipla e irredutível. Por isso, Nascimento percebe uma revisão senão da história planetária (tarefa desmensurada e impossível), ou mesmo latinoamericana, mas de um fragmento dessa história por meio da literatura da escritora brasileira, 
visto que, em Clarice, homens e animais se cruzam nesta epopeia intimista que não examina o homem isoladamente, mas em relação a tudo que o cerca.

"O búfalo", nesse sentido, problematiza os limites do humano ao tratar de animais em íntima relação com o homem. Em uma esfera mais ampla, a obra da escritora como um todo trata da relação do humano com objetos, paisagens, coisas, cores, trechos musicais, ruídos e silêncios, na intenção de questionar os limites da interioridade humana. Em outras palavras, a escritora colocou em cena aquilo que não ameaça o homem, mas sim problematiza sua individualidade identitária frente aos outros. Não se trata, porém, de psicanalisar as relações entre humanos e bichos, mas de compreender um certo estranho familiar que os bichos trazem em si ao se relacionar com o homem. Para a literatura moderna, o bicho tornou-se não somente um adorno para a obra, ele atinge um caráter enigmático, aquilo que é ininteligível e até mesmo impalpável. Ele é "um ser enigmático que nos coloca de pronto em face de um duplo mistério, o da animalidade, naquilo que esta se comunica com o mistério da diferença humana" (NASCIMENTO, 2012, p. 30).

A crítica ocupada com a obra de Lispector já tratou, pontualmente, da importância dos animais na ficção da escritora. Desde a infância, Clarice se viu rodeada por eles: gatos, galinhas, cachorros e todo tipo de animal doméstico. Ela os observava como se quisesse entender o íntimo do outro, a exemplo da galinha, protagonista dos contos "Uma Galinha" e "O ovo e a Galinha", publicados respectivamente em Laços de família (1960) e Felicidade clandestina (1971), a partir dos quais Clarice comenta, dirigindo-se em resposta a um jornalista: "Eu entendo uma galinha, perfeitamente. Quero dizer, a vida íntima de uma galinha, eu sei como é" (LISPECTOR apud GOTLIB, 1995, p. 66). Segundo Nádia Gotlib, Clarice quando menina já observava os animais. Em $A$ vida intima de Laura (1974), a narradora, por exemplo, conta histórias de galinhas e dirige-se à criança-leitora do livro da seguinte maneira: "Quando eu era do tamanho de você, ficava horas e horas olhando para as galinhas. Não sei por quê. Conheço tanto as galinhas que podia nunca mais parar de contar" (LISPECTOR, 1999b, s.p.).

Podemos averiguar, em vários textos de Clarice, uma espécie de dupla metamorfose em que a condição animal do ser humano e a condição humana do animal se põem como dois dos pilares de sustentação da vida mestra do pensamento ficcional da escritora. Isso ocorre, segundo Silviano Santiago (2006), pois "os processos de automodelagem do humano como animal doméstico e de modelagem dele como animal selvagem (pelo olhar alheio ou pelo próprio olhar) torna-se frequente na prosa da escritora" (SANTIAGO, 2006, p. 160). Essa automodelagem apontada por Santiago é notável em "O búfalo", visto que a personagem parece encontrar a plenitude de seus sentimentos dentro do zoológico, sobretudo a partir de seu contato com o animal.

De acordo com Santiago, a automodelagem do ser humano como animal aponta para uma espécie de paz interior, um sossego do ser no mundo. Em "O Búfalo", o sentimento de reciprocidade da mulher é direcionado ao inumano que, salvo engano, pode simbolizar o homem que tanto precisava odiar. Em outras palavras, ela acaba por encontrar no animal uma plenitude de vida, reconhecida, por sua vez, no prazer sentido (externalização da raiva), quando, ao mesmo tempo, sente-se satisfeita com a espécie de vingança traduzida pelo olhar do animal que, de início, também a desprezava.

Em determinada passagem do conto, a mulher provoca o animal fitando-o, até que ele volta sua atenção totalmente a ela. Nesse momento, ocorre uma dupla metamorfose, pois o búfalo transmite, em seu olhar, o ódio que seria em tese humano e a mulher, por conseguinte, passa a sentir ódio, mesclando-o ao amor pelo búfalo, instintivamente, humanizado. Esse 
processo demonstra a automodelagem do humano no animal através de uma reciprocidade única e inigualável, como vemos a seguir:

O primeiro instante foi de dor. Como se para que escorresse este sangue se tivesse contraído o mundo. Ficou parada, ouvindo pingar como numa grota aquele primeiro óleo amargo, a fêmea desprezada. Sua força ainda estava presa entre barras, mas uma coisa incompreensível e quente, enfim incompreensível, acontecia, uma coisa como uma alegria sentida na boca. Então o búfalo voltou-se para ela.

O búfalo voltou-se, imobilizou-se, e à distância encarou-a.

Eu te amo, disse ela então com ódio para o homem cujo grande crime impunivel era o de não querê-la. Eu te odeio, disse implorando amor ao búfalo (LISPECTOR, 2009, p. 134, grifo nosso).

A automodelagem do ser humano como animal selvagem advém do anúncio de um conflito interpessoal, uma vez que há um estranhamento/reconhecimento entre a mulher e o búfalo. Vale ressaltar que a mulher do conto se sente, em vários momentos, incomodada frente ao olhar dos animais. Esse olhar lançado sobre a personagem funciona como um questionamento investigativo que procura, bem ao contrário do que se espera, estabelecer uma comunicação recíproca entre os seres. É nesse sentido que a mulher se sente modelada pelos animais e torna-se, metaforicamente, o coração selvagem fora da jaula em livre passeio pelo zoológico.

Como ressaltado, tal modelagem acionada pelo olhar do outro traz à mulher o questionamento de sua própria humanidade. Essa indagação sugere a ela, como se fosse possível, um escape da racionalidade, o qual concederia ao ser a vivência em seu puro contentamento animal, bem distante da lucidez racional, marcada pelas hesitações típicas da vida humana: o medo, a morte, a saudade, entre outras.

Os processos de automodelagem do humano como animal doméstico e como animal selvagem (olhar do estranho) se fazem presentes ao longo dos textos da escritora. No conto em questão, Lispector aproxima a mulher do que há de mais selvagem entre os animais do mundo (os animais do zoológico, o búfalo, por exemplo). É como se quisesse questionar essa relação indo além do meramente biológico, pois, segundo a narrativa, parece ser perfeitamente possível que o homem se comunique com o animal e vice-versa, por meio de aproximações mediadas por toque ou outras formas de sentidos, a exemplo do próprio olhar. Essas proposições tornamse coerentes à medida em que a personagem se depara com situações tipicamente humanas ocorridas dentro das jaulas do zoológico:

\footnotetext{
Até o leão lambeu a testa glaba da leoa. Os dois animais louros. A mulher desviou os olhos da jaula, onde só o cheiro quente lembrava a carnificina que ela viera buscar no Jardim Zoológico [...]. Mas isso é amor, é amor de novo, revoltou-se a mulher tentando encontrar-se com o próprio ódio mas era primavera e dois leões se tinham amado (LISPECTOR, 2009, p. 126, grifo nosso).
}

Como podemos perceber no fragmento, a modelagem do animal em humano e do humano em animal se misturam e se confundem na cena em que a mulher (fêmea) percebe o carinho do leão para com a leoa. Tal cena constrange a personagem que vê reproduzido entre os animais aquilo que ela esperava de sua própria vida: o carinho do homem que não a amava. Desse modo, a imagem representativa do amor dentro da jaula provoca, na mulher, o sentimento oposto: o ódio. Assim, para a personagem, a visita às jaulas tenciona modelar tanto os animais, 
quanto a si mesma, em uma via crucis da busca pelo amor e pelo ódio, "no mundo de primavera" (LISPECTOR, 2009, p. 134) e desilusões.

\section{Considerações finais: Clarice Lispector e "O motivo do olhar"}

Inocente, curiosa, entrando cada vez mais fundo dentro daqueles olhos que sem pressa a fitavam, ingênua, num suspiro de sono, sem querer nem poder fugir, presa ao mútuo assassinato. Presa como se sua mão se tivesse grudado para sempre ao punhal que ela mesma cravara. Presa, enquanto escorregava enfeitiçada ao longo das grades. Em tão lenta vertigem que antes do corpo baquear macio a mulher viu o céu inteiro e um búfalo (LISPECTOR, 2009, p. 135, grifo nosso).

Com base na leitura aqui proposta, podemos dizer que Clarice Lispector ficcionalizou, por intermédio de uma poética do olhar, a existência do animal (não) humano em seu conto. Este procedimento toma como ponto de partida o encontro cotidiano do homem e do animal inumano, fazendo com que aquele entenda o seu próprio modo de agir e demonstrar emoções em frente ao outro, ao mundo, ao estranho. Entre desejo e medo, amor e ódio, a personagem clariciana é levada ao limite máximo de sua humanidade, principalmente quando se vê refletida no olhar do búfalo, olhar que concede "voz" ao inumano, embora ele não fale a palavra dos homens.

$\mathrm{O}$ sujeito que se assiste viver coloca-se no cenário exterior em que os outros o colocaram, adotando uma forma de pensar e agir de acordo com o ser coletivo que o vigia e por quem se automodela, em uma espécie de identidade em terceira pessoa que lhe foi conferida. Sua experiência reflexiva converte-se no reflexo oblíquo de alguém que o humano (neste caso, a mulher do conto), incialmente, não vê. Todavia, conforme já ressaltou Benedito Nunes, ao ver os outros, os outros nos veem, pois "mais firme e forte nos parece a correlação aventada, à luz do outro motivo recorrente da ficção de Clarice Lispector: o motivo do olhar (NUNES, 1995, p. 107, grifo do autor).

Atravessada por esse motivo, a literatura animal de Clarice Lispector desfigura os preceitos ocidentais sobre o homem e o animal, visto que os humanos tendem a rebaixar tudo o que os difere, tudo que acreditam não servir aos olhos da racionalidade. Em suma, a figura do animal não humano, em "O búfalo", procura intensamente desfigurar a logocêntrica e ocidental visada que legislou sobre os preceitos da relação homem/animal ao longo dos tempos. Logo, a prosa da escritora assume o papel de uma literatura pensante, já que perde "sua condição exclusivamente filosofante para ser um dado do sentimento-experiência que a proximidade com os bichos, por exemplo, possibilita" (NASCIMENTO, 2012, p. 36).

A relação humano/animal e o motivo do olhar são os dois aspectos sustentadores, no conto de 1960, dessa escrita poética que reinscreve o animal enquanto matéria histórica, social e estética, fazendo da literatura clariciana o local propício para uma "política da vida" (GIORGI, 2016, p. 116). Política que desconstrói as falsas oposições entre o humano e o inumano (Jacques Derrida), bem como reconhece o homem em sua condição de sujeito aberto ao mundo (Giorgio Agamben). Assim, em Clarice, a ordem do visível torna-se máxima operante para que a personagem humana do conto se mostre não em essência, mas em estado de relação junto a outros viventes. 


\section{Referências}

AGAMBEN, G. O aberto. Tradução: Paulo Mendes. Rio de Janeiro: Civilização Brasileira, 2017.

ARISTÓTELES. História dos animais. Lisboa: Imprensa Nacional - Casa da moeda, 2006.

BORGES, J. L.; GUERRERO, M. Manual de zoología fantástica. México: Fondo de Cultura Económica, 1957.

DERRIDA, J. O animal que logo sou (a seguir). Tradução: Fábio Landa. São Paulo: Unesp, 2002.

GIORGI, G. Formas comuns: animalidade, literatura, biopolítica. Tradução: Carlos Nougué. Rio de Janeiro: Rocco, 2016.

GOTLIB, N. B. Clarice, uma vida que se conta. São Paulo: Ática, 1995.

LISPECTOR, C. Laços de Família. Rio de Janeiro: Rocco, 2009.

LISPECTOR, C. A descoberta do mundo. Rio de Janeiro: Roco, 1999a.

LISPECTOR, C. A vida íntima de Laura. Rio de Janeiro: Rocco, 1999b.

LISPECTOR, C. A paixão segundo G.H. Edição crítica. Coordenação de Benedito Nunes. 2a ed. Madrid; Paris; México; Buenos Aires; São Paulo; Rio de Janeiro; Lima: ALLCA XX, 1996. (Colección Archivos)

MACIEL, M. E. Literatura e animalidade. Rio de Janeiro: Civilização Brasileira, 2016.

NASCIMENTO, E. Clarice Lispector: uma literatura pensante. Rio de Janeiro: Civilização Brasileira, 2012.

NUNES, B. O drama da linguagem: uma leitura de Clarice Lispector. São Paulo: Ática, 1995.

RIBAS, R. O aberto: o homem e o animal de Giorgio Agamben - uma tentativa hipertextual. Pensando, v. 04, n. 08, 2013. p. 1-30. Disponível em http://www.ojs.ufpi.br/index.php/pensando/article/view/1418/1411. Acesso em 15 out. 2020.

SANTIAGO, S. O bestiário. In: SANTIAGO, S. Ora (direis) puxar conversa! Ensaios Literários. Belo Horizonte: Editora UFMG, 2006, p. 157-191.

SILVA, M. F. S. Introdução. In: ARISTÓTELES. História dos animais. Lisboa: Imprensa Nacional - Casa da moeda, 2006. p. 11-44. 